\section{Research Article}

(c) 2021 Hussein et.al..

This is an open access article licensed under the Creative Commons Attribution-NonCommercial 4.o International License

(https://creativecommons.org/licenses/by-nc/4.o/)

\title{
Employees Retention Strategy and its Impact on Organizational Memory: An Exploratory Research for the opinion of Faculty Members at Private Colleges on Baghdad
}

\author{
Dr. Abbas Mohammed Hussein \\ Imam Ja'afar Al-sadiq University, \\ Qahira, Baghdad, Iraq \\ Dr. Majeed Hameed Taher \\ Imam Ja'afar Al-sadiq University, \\ Qahira, Baghdad, Iraq \\ Luma Majid Hameed \\ Al-Ma'moon University, \\ 14 Ramadan St, Baghdad, Iraq
}

DOI: https://doi.org/10.36941/ajis-2021-0o3o

\section{Abstract}

The research aims to determine the impact of employees' retention strategy on organizational memory. This research is historical, descriptive, and analytical. The sample consists of 158 faculty members in five private colleges in Baghdad. The technique used to analyze the data is SEM (Structural Equation Modeling), and SPSS (Statistical Package for the Social Sciences). The research concludes that the employees retaining strategy plays a vital role in retaining employees and hence maintains organizational memory. The findings and recommendations of this research assure the administrations of private colleges that employees retention strategy play a vital role in retaining its employee and hence maintains organizational memory. This research differs from the previous researches in that it has not examined the reasons for leaving employees or the turnover, but looking for the reasons that inspire employees to remain in the organization. This research suggests that employees' retention strategy helps the organization retain its employees, and as a consequence, maintaining organizational memory.

Keywords: Employees, Employees Retaining Strategy, Memory, Organizational Memory

\section{Introduction}

The business environment shifted from the manufacturing economy to the knowledge economy, which makes knowledge a key to competitive advantage. This change is followed by an increase in appeals from $\mathrm{OB}$ and HRM specialists to redesigning a work environment to make it compatible with knowledge work (Maier et al, 2009) (Mladkova, 2011). Based on the premise that knowledge workers 
are highly powerful in organizations, knowledge is a main competitive factor (Maier, 2002).

The OT and HRM literature confirm that organizations are nothing more than an extension of human thinking and action, and the organization's value is generated by the knowledge and skills of individuals (Baron \& Armstrong, 2007). RBV theorists argued for a decade that intangible assets were the engine of competitive advantage (Quinn, 1992) (Conner \& Prahalad, 1996). So, if the organization wants to establish a competitive advantage, strategic resources must be created, built, and retained (Wernerfelt, 1984). Which is characterized by scarcity, value, difficulty to imitate, and replacement (Barney, 1991). In this vein (Sydler et al, 2013) assert that the knowledge meets all the features that Barney has listed. So, it is the main resource of the Organization (Spender \& Grant, 1996). And how the organization generates, utilizes, and retains knowledge can influence its performance, and thus its competitiveness (Grant, 1996).

Knowledge is divided into explicit knowledge which easy to codify and formalize (Koenig and Membrillo, 2000). And tacit knowledge, that's in employee's minds and hard to codify (Penning \& Harianto, 1992). So, the process of transformation knowledge from tacit to organizational memory is a process that challenging and difficult to master, given its intangible, personal, and intuitive nature (Hatami et al, 2003). and where explicit knowledge accounts 30\% of the knowledge owned by the organization, and the remainder is tacit knowledge (Al-Ali, 2003). And because employees have freedom of movement between organizations, this poses the main challenge and puts immense pressure on organizations to establish a strategy for maintaining employees and the knowledge they possess. Research is therefore required to explore the connection between employee retention strategy and organizational memory. After reviewing the literature to show the nature of the impact models between these variables, we did not reach tangible results, therefore, this research was conducted to test this model.

\section{Literature Review}

\subsection{Employees Retention Strategy}

Numerous attempts to establish a clear definition for Employee Retention strategy were made. some scholars refer to it as the proportion of employees remaining in the organization (Phillips and Connell, 2003). (Armstrong, 2006) describe it as creating a strategy to retain the employees. While (Stewart and Brown, 2011) define employee retention strategy as a series of steps intended to retain employees after they have been hired. It is initiatives taken by the organization to keep the employees (Mahal, 2012). And it is voluntary actions performed by the organization to increase employee satisfaction and the desire to stay for a long time (Idris, 2014). It refers to the efforts made by the employer to maintain desirable employees to attain business objectives (Frank et al, 2004). (Vasantham and Swarnalatha, 2016) claim that employee retention strategy is the procedures and methods that organizations use to prevent important employees from leaving the organization. It is, therefore, the organization's systematic efforts to build and improve the working environment that encourages employees to remain in an organization through the creation of policies and practices which meet the various needs (Mathiamaran and Kumar, 2017).

The issue of retaining employees represent one of the biggest challenges confronting organizations (Vasantham and Swarnalatha,2016). Organizations searched for mechanics to enhance their attractiveness as a good place to work and to reduce costs associated with unexpected job turnover (Chang et al,2013). In this vein (Dibble, 1999) comment on this issue by saying that the challenge confronts by organizations in seeking and retaining qualified employees who make it successful is the outcome of a revolution, And this revolution stems from a modern perception of employees' position in organizations. Hence the retention of a good employee is important for the organization because the competitive advantage stems from the creation of a loyal workforce (Stewart and Brown,2011). organizations that use good practices to retain employees will not only ensure the enhancement of its business, but will ensure the reduction of turnover costs, improved productivity 
and efficiency in the implementation of business processes, and the speed of access to markets, consistency in customer service, increase customer loyalty and retention them (Ware,2001).

Employee retention strategy is not influenced by one factor, rather there are several factors responsible for retaining employees (Das and Baruah, 2013). The best retention strategies are multifunctional (Dessler, 2013). Below some of which:

1. Positive working environment (PWE): The work environment reflects a social and professional setting in which employees may engage with each other to carry out the work collaboratively (Swamy, 2013). The features of this setting influence the degree to which the employees embrace it, the latter reflects the possession by the organization a working environment in which practice, procedures, and regulations are structured to allow employees to achieve organizational goals and personal satisfaction (Disch, 2002).

2. Employee involvement (EI): Participatory management is widely regarded as an integral aspect of the productive working environment, the purpose of such an environment is to bring employees together to influence the work environment by participation in the job-related decision-making process, in this way, self-confidence and happiness are improved. Therefore, the management accountable for satisfying the need of employees to be active participants in daily decisions concerning their jobs and the organization as a whole (Kiernan \& Knutson, 1990).

3. Compensation \& Benefits (CB): Compensation \& benefits are the most significant financial revenues that meet the employee's needs; it is the power that motivates the employees to complete their tasks (Gagne, 2014). Therefore, the degree to which the organization ties the rewards and payment system to its strategic plans encourages employees to strive to fulfill the business needs and requirements (Varghese \& Jayan, 2013). Pay encouraging employees to carry out the organization's interests (Kling, 1995).

4. Management support (MS): Often shows interest in employees through the level of support provided by management, the latter relates to the level of a sense of employees appreciated their contributions and attention to their well-being by the organization (Fapohunda,2011). Thus, the employee's commitment towards the organization will be effected by their perception level to support and commitment of the organization towards them (Drury,2006).

5. Teamwork (TW): Bureaucratic management activities restrict the contact between employees and managers about which methods are used to carry out the work (Gittell et al, 2007). As a result, calls have been made to redesign the working environment (Godwyn \& Gittell, 2012). These calls have been integrated into the post-bureaucratic organizational systems where everyone is accountable for the performance (Turniansky \& Hare, 1998:103).

6. Training and development (TD): High-performance organizations depend on the skills of employees to carry out business and problem solving (Pfeffer,1998). Organizations facing a rapidly changing world depend on the skills of employees to solve potential problems. This emphasizes the importance of training and development in providing employees with the necessary skills (Kling, 1995). training and developing aims to improving employees' skills through training, career planning, and business restructuring (Meifert,2013).

7. Employee freedom and flexibility (EFF): In contemporary theories of motivation and job design autonomy is a fundamental principle (Dysvik \& Kuvaas,2011). It is defined as the degree of freedom that an employee possesses when performing work tasks (Wang et al, 2013). Autonomy can be categorized into autonomy in work schedules, working methods, and decision-making (Niessen \& Volmer,2010).

8. Employee communication (EC): Management should assess, evaluate the effectiveness of each program, should interpret that to employees, and take their initiatives (Ahmad, 2013). For two reasons, information sharing is a vital component of high-performance systems, The first is that the sharing of information reveals some aspects such as financial, strategic, and organizational efficiency, which demonstrate to employees why the organization is trusted, The second is that the best employees cannot make contributions that increase the 
organizational efficiency until they have information about key aspects in the organization (Pfeffer,1998).

\subsection{Organizational Memory Definition}

Organizational memory (OM) is a concept that has no single, universally accepted definition (Atwood, 2002). And become overworked and confused (Ackerman and Halverson, 1999). And it's a construct that is loosely defined and underdeveloped and is multi-faceted (Girard, 2009). Therefore, many researchers attempt to define this concept, (Anand et al,1998) define it as a convenient metaphor that can be used to define the information and knowledge known by the organization and the processes by which information is acquired, stored, and retrieved by organization members. OM has also been defined by ( $\mathrm{Li}$ et al,2004) as a sum of knowledge assets that organizations owned. In this vein (Farooq,2018) assert that Organizational memory is a type of coding strategy where explicit knowledge is stored and saved at the organizational level. This information is derived from an organization's history that can be brought to bear on present decisions (Schmitt et al,2012). And firm's critical knowledge, skills, and capabilities-embedded in its human resources-contribute actively to its success (Schmitt et al,2012). after reviewing the literature, the researchers concluded that previous researches focused on considering Organizational memory from multiple approaches, Such as organizational behavior, organizational learning, computer science and management information system, information science, Or through the influence of Organizational memory on The social context and the creation of knowledge, and their impact on the Administrative process, and the performance of the product and creativity, and development.

1. Social knowledge (SK): A social relations between employees within the organization, or between the organization and its customers and partners structures (Cam et al,2018). According to Cross et al. (2003) high performing employees are characterized by their ability to create, maintain, and utilize personal networks.

2. Job knowledge (JK): Job knowledge refers to knowledge that enables effective job performance (DeLong, 2004) is a direct determinant of job performance (Ones et al,2017:292). Employees know this type of knowledge, understand the strategy and basic management method, thus employee can do as the request of management ( $\mathrm{Li}$ et al, 2004:3). This knowledge consists of declarative, procedural, and process knowledge (Van Fleet, 2014:61).

3. Corporate knowledge (COK): It Is accessed, shared, re-used, and updated by the organization's employees during the process of completing their assigned tasks (Gerogiannakis et al). Knowledge is the core of organizational memory ( $\mathrm{Li}$ et al,2004). Corporate knowledge that is representing prior experiences and is saved and shared by users (Pai et al,200o).

4. Industry knowledge (IK): (Kransdorff and Williams,200o) referred to the knowledge of the organization's market. Market knowledge is the collection and analysis of data on target markets by identifying the market size and market share expected in a position to serve, as well as forecasting growth rates of the markets served by the organization and enable it to determine the needs and desires of customers and the nature of the competition, Access to market knowledge requires A study three basic elements, knowledge of customers, knowledge of competitors and knowledge of research and development (Kotler,200o).

5. History $(\mathbf{H})$ : The importance of the history of the organization in determining its future actions (Boeker, 1989). The organization's history is important for future growth, and cannot understand the organization only in the light of the early stages of development (Phan et $\mathrm{al}, 2008)$. A shared history is a large part of what binds individuals into a community and imbues a group with a distinct identity, the history of the enterprise can instill a sense of identity and purpose and suggest the goals that will resonate. (Seaman and Smith, 2012). (Day,1994) assert that Organizations without practical mechanisms to remember what has worked, and why, will have to repeat their failures and rediscover their success formulas over and over again. 
6. Political knowledge (PK): Political knowledge of an organization is vital to successfully navigate organizational life and for gaining access to necessary resources. It involves an understanding of management and decision-making styles (Kransdorff and Williams, 200o). To maintain operations and to achieve task continuity in circumstances where the failure of formal authority may otherwise cause problems (Schermerhorn et al,2002).

7. Cultural knowledge: Cultural knowledge including that of shared beliefs, values, and norms, is also an integral part of organizational memory (Kransdorff and Williams, 200o). (Schein, 2004) refers to culture as "patterns of shared assumptions learned by a group". Items were generated that tapped into an understanding of organizational norms, values, and priorities.

\subsection{Relationship Between Employees Retention Strategy and Organizational Memory}

Many arguments assert that the employee plays a central role in organizational memory, and when this employee leaves an organization, that memory will be harm. Employees are the cognitive element in organizational memory (Stijn \& Wensley, 2001). Although all organizations technology-driven, human resources are still required to run that technology (Mathiamaran \& Kumar,2017). Employee interaction with the world may lead to outcomes that are interpreted and shared by them, and this will create shared beliefs, values, assumptions, norms, and behaviors which a base of organizational memory (Moorman \& Miner,1997). As well as employee cognitive activities play a central role in acquisition knowledge (Walsh \& Ungson, 1991). And then store knowledge in their mind and ability to remember and articulate experience in the cognitive orientation that they employ to facilitate information processing (Walsh \& Ungson, 1991). The employee uses their tacit knowledge to put explicit knowledge into action an effective way (Schmitt et al, 2012). Only 10 to 30 percent of organization knowledge is explicit which codified in databases and manuals, the rest is tacit knowledge which means that employee's brainpower is the most important resource in the value creation process (AL-Ali, 2003). The reality is that organizations are nothing more than an extension of human thought and action, it is the knowledge, skills, and abilities of an individual that create value (Baron \& Armstrong,2007). All the above argument reaches us to conclude that employee memory is distinct from organizational memory (Stein \& Zwass, 1995).

Many studies have been made to identify the condition that influences an employee's decision to leave or stay the organization. (Maslach and Jackson,1986) found that the absence of a good work environment leads to various negative outcomes such as employee absenteeism, health problems, work turnover, and a declining commitment to work. While other studies concluded that management support increases employee commitment and their obligation towards the organization (Eisenberger et al, 2001). Alan Price (2004) asserts that the reward system helps in recruiting and retaining a good employee. Moncarz (2008) concluded that pay, goals and direction, employee recognition, rewards, and organizational mission have a significant impact on employee retention. Stone et al (2010) observed that monetary and material incentives maybe not always be welcomed by some employees because it does not satisfy the basic psychological need of the employee. In this vein, previous studies assert that $88 \%$ of professional employees' departure the organizations for reasons that are not based totally on the money, but the main reasons were insufficient development opportunities (39\%), unsatisfied with management (23\%), lack of recognition (17\%) (Hill and Tande,2006). Nadeem Sohail (2011) found that compensation, career path, and work environment have a positive impact on employee retention.

The OT and HRM literature confirm that organizations are nothing more than an extension of human thinking and action, and the organization's value is generated by the knowledge and skills of individuals (Baron \& Armstrong, 2007). thereby when a qualified employee leaves the organization, it will lose crucial skills, knowledge, and business relationships (Latha, 2017). As a consequence, the organization will incur the cost of loss of organizational memory (Ongori,2007).

The above discussion shows the significance of the retention of an employee. And in an age where globalization, innovation, and market integration making knowledge primary sources for competitive advantage (Hatami et al, 2003). The organization should start focusing on employee retention as is the only source of competitive advantage (Raghavan, 2011). To ensure that key employee stays with the 
organization and that wasteful and expensive level of employee turnover are reduced (Armstrong, 2006). These assert results from a straight recognition that employee who leaves represent a lost resource in which the organization invested time and money (Torrington et al, 2008).

\section{Methodology}

The changes in organizations since the advent of the new millennium are characterized by the transition from the industrial to the knowledge economy, Which globalization, the intensity of competition, and growing emphasis on knowledge are the most important manifestations, these changes have been followed by threats to the organizations, which are moving employees freely between organizations. This fluidity presents a new challenge for an organization (Conklin, 1997). Because when an employee leaves the organization, it loses the source of a competitive advantage which is his employee's knowledge. HRM Therefore calls to developing a strategy to ensure that key employees remain in the organization. Under this, a problem arises, representing in determining the acceptable working conditions that make an employee who has knowledge highly motivated as well as adhere to the organization and not leaving and thereby maintains organizational memory. From here, the research seeks to address the key question which is: What is the impact of Employees retaining strategy on organizational memory?

Despite the attention given to the topic of employee retention strategy and organizational memory on theoretical literature, an analysis of previous studies reveals several facts; firstly, most of the recent research appears to focus on turnover rather than retention (Huang et al, 2006). Therefore, it suffers from a lack of field research. Second, the dilemma of the departure of the qualified employee remains unsolved (revlander and Evans, 2007). Third, there is no sufficient evidence on the design of the work environment that helps maintain employees who have knowledge (Roy, 2012). Fourthly, despite the widespread significance of retaining employees, few studies have been conducted to explore this term (Al-Damoe et al, 2012). moreover, earlier research has focused on either the reasons why employees leave the organization or the reasons for job turnover, but few have focused on the reasons why employees stay in organizations (Vispute, 2013). Fifth, there is inadequate evidence about the impact of employees' retention strategy on organizational memory. Sixth, the analysis also showed mixed results in that impact, making a definitive conclusion difficult to draw. Seventh, the previous studies were largely neglected, that is, they focused on the employee retention strategy, or organizational memory and did not study together, and eighth, the analysis also showed that most previous studies were conducted in developed countries, where the working environment is different from developing countries, especially the Arab countries.

In light of the above facts, the research stems its importance from its effort to, first, enhancing the concepts of employee retention, and organizational memory, discussing how to build a work environment that will help to implement effective practices as a means of retaining employees and clarifying their importance in theory and practice. Second, examining the impact of employees' retention strategy on organizational memory makes it easy to reach a definite conclusion, especially, in developing countries with particular reference to Iraq. Third, this research differs from the previous research in that it has not examined the reasons for leaving employees or the turnover, but looking for the reasons that inspire employees to remain in the organization.

Employee retention emerges as the most urgent issue for HRM (Sinha and Sinha, 2012:145). In light of this, the research aims to assess the impact of employees retention strategy on organizational memory, As well as a sub-objectives linked in essence to empirically explore the impact models between its dimensions, Contributing to the theoretical and philosophical framework of the research variables, by tracking the theoretical paths of the specialized literature, and connect them in the context of scientific research which enriching organizational literature. diagnosing the reality of the research dimensions in a sample of colleges, and to make a collection of recommendations to inform the administrations of these colleges the importance of providing their employees with a suitable working environment to motivate them to stay and to ensure that it is organizational memory, not 
harm. Finally, diagnose the impact of employees' retention strategy on organizational memory.

The research population spread over 678 participants works in five colleges (AL-Turath, ALRafidain, Baghdad Economic Sciences, and the Dijlah, and AL-Esraa). to estimate the required sample size according to the multiple regression model, the following equation can be used $\mathrm{N}>50+\mathrm{m}$ (Green,1991). by application, the researchers note that the equation indicates that the required sample size needed was estimated at a minimum (98) participants, so the researchers distributed (200) questionnaires and returned (158) of them.

The data of the research was collected by using a structured questionnaire. The questionnaires pre-tested for their validity and reliability. The questionnaire consisted of three sections, The first dealt with demographic information of the research sample, the second section dealt with employee retention strategy, which consists of 40 statements on Positive work environment (5), Employee involvement (5), Compensation \& benefits (5), Management support (5), Team working (5), Training \& development (5) Employee freedom \& flexibility (5) Employee communication (5) (Kiruthiga and Magesh, 2014). And the last section dealt with organizational memory which consists of 35 statements on Social knowledge (5), Job knowledge (5) Corporate knowledge (5) Industry knowledge (5) History of the organization (5) Political knowledge (5) Cultural knowledge (5) (Dunham and Burt, 2014). The research uses a five-point rating scale (Likert's Scale).

The participants were 85 ( 54 percent) male and 73 (46 percent) female. The participant age was 40 (from 30 Less than 35), (25 percent), 50 (from 35 and less than 40) (31 percent). 40 (40 - and less than 45 ), ( 25 percent), 28 (50 and above), (17 percent). The participants hold a master's degree was 50 (31 percent), followed by doctoral degree holders 78 (49 percent) and diploma by 30 (18 percent).

Table (1), show the internal consistency of the scale at the dimensional level. As we can note the values of the correlation coefficients (Cronbach Alpha) exceeded the acceptable minimum of (o.70), confirming the internal consistency of the scale and the stability.

Table (1): Internal Consistency Test for Variables and Dimensions

\begin{tabular}{|l|c|l|c|}
\hline The scale & $\begin{array}{c}\text { Alpha Kronbach } \\
\text { coefficient }\end{array}$ & The scale & $\begin{array}{c}\text { Alpha Kronbach } \\
\text { coefficient }\end{array}$ \\
\hline Positive work environment & 0.85 & History & 0.87 \\
\hline Employee involvement & 0.79 & Political knowledge & 0.83 \\
\hline Compensation \& benefits & 0.86 & Corporate knowledge & 0.84 \\
\hline Management support & 0.81 & Job knowledge & 0.84 \\
\hline Team working & 0.71 & Social knowledge & 0.86 \\
\hline Training \& development & 0.70 & Industry knowledge & 0.87 \\
\hline Employee freedom \& flexibility & 0.71 & Cultural knowledge & 0.89 \\
\hline Employee communication & 0.78 & All questionnaire & 0.97 \\
\hline
\end{tabular}

\section{Results}

\subsection{Structural Equation Modeling}

The equation of structural modeling has been widely accepted and used in management research (Moutinho and Hutcheson, 2011). As it provides researchers with comprehensive means to evaluate and modify theoretical models, thus providing great potential for promoting the development of the theory (Whitman, and Woszczynski, 2004). Therefore, to check sufficient and discriminant validity among all variables of research we used CFA. The CFA analysis for employee retention strategy showed that the model has obtained good values $\left(\mathrm{X}^{2}=1.99, \mathrm{GFI}=0.69\right.$, AGFI $=0.65, \mathrm{RMSE}=0.08, \mathrm{NFI}=0.63, \mathrm{CFI}=0.77$, $\mathrm{TLI}=0.75$, IFI $=0.78)$, and for organizational memory the CFA analysis showed that the model has obtained good values $\left(\mathrm{X}^{2}=2.26, \mathrm{GFI}=0.70, \mathrm{AGFI}=0.65, \mathrm{RMSE}=0.09, \mathrm{NFI}=0.71, \mathrm{CFI}=0.81, \mathrm{TLI}=0.79\right.$, IFI $=0.82$ ), which indicates the possibility of accepting the model formed by the researchers. 
It is clear from Table (2) (3) that all model estimates are significant below o.o1 and CR values are greater than (1.96). This indicates the validity of the hypothesis that the vertebrae of each dimension are capable of measuring, accepting the values of the coefficients of truthfulness or saturation which govern acceptance, and that it satisfies the condition as greater or equal (o.40), i.e., the acceptance of not less than 0.40 (Costello \& Osborne, 2005).

Table (2): Estimates of the Employees Retention Strategy $n=158$

\begin{tabular}{|c|c|c|c|c|c|c|c|}
\hline & & & Estimate & S.E. & C.R. & $\mathrm{P}$ & Label \\
\hline VR5 & $<---$ & PWE & 1.000 & & & & \\
\hline $\mathrm{VR}_{4}$ & $<---$ & PWE & .867 & .101 & 8.597 & $* * *$ & par_1 \\
\hline $\mathrm{VR}_{3}$ & $<---$ & PWE & .882 & .109 & 8.126 & $* * *$ & par_2 \\
\hline $\mathrm{VR}_{2}$ & $<---$ & PWE & 1.077 & .111 & 9.706 & $* * *$ & par_3 \\
\hline VR1 & $<---$ & PWE & 1.126 & .117 & 9.647 & $* * *$ & par_4 \\
\hline VR1o & $<---$ & EI & 1.000 & & & & \\
\hline VR9 & $<---$ & EI & 1.478 & .180 & 8.207 & $* * *$ & $\mathrm{par}_{-5}$ \\
\hline VR8 & $<---$ & EI & 1.085 & .177 & 6.143 & $* * *$ & par_6 \\
\hline $\mathrm{VR}_{7}$ & $<---$ & EI & .916 & .127 & 7.219 & $* * *$ & par $_{-7}$ \\
\hline VR6 & $<---$ & EI & .873 & .138 & 6.336 & $* * *$ & par_8 \\
\hline VR15 & $<---$ & $\mathrm{CB}$ & 1.000 & & & & \\
\hline VR14 & $<---$ & $\mathrm{CB}$ & 1.219 & .134 & 9.067 & $* * *$ & par_9 \\
\hline VR13 & $<---$ & $\mathrm{CB}$ & 1.290 & .145 & 8.907 & $* * *$ & par_10 \\
\hline VR12 & $<---$ & $\mathrm{CB}$ & 1.254 & .155 & 8.096 & $* * *$ & par_11 \\
\hline VR11 & $<---$ & $\mathrm{CB}$ & 1.117 & .139 & 8.022 & $* * *$ & par_12 \\
\hline VR2O & $<---$ & MS & 1.000 & & & & \\
\hline VR19 & $<---$ & MS & 1.662 & .269 & 6.183 & $* * *$ & par_13 \\
\hline VR18 & $<---$ & MS & 1.737 & .273 & 6.352 & $* * *$ & par_14 \\
\hline VR17 & $<---$ & MS & 1.630 & .280 & 5.814 & $* * *$ & par_15 \\
\hline VR16 & $<---$ & MS & 1.714 & .279 & 6.142 & $* * *$ & par_16 \\
\hline$V_{25}$ & $<---$ & $\mathrm{TE}$ & 1.000 & & & & \\
\hline$V_{24}$ & $<---$ & $\mathrm{TE}$ & 1.462 & .192 & 7.628 & $* * *$ & par_17 \\
\hline VR23 & $<--$ & $\mathrm{TE}$ & 1.111 & .181 & 6.126 & $* * *$ & par_18 \\
\hline VR22 & $<---$ & $\mathrm{TE}$ & .793 & .148 & 5.365 & $* * *$ & par_19 \\
\hline VR21 & $<---$ & $\mathrm{TE}$ & .827 & .159 & 5.215 & $* * *$ & par_2o \\
\hline$V_{3} 30$ & $<---$ & $\mathrm{TD}$ & 1.000 & & & & \\
\hline VR29 & $<---$ & TD & .849 & .193 & 4.403 & $* * *$ & par_21 \\
\hline$V_{2 R} 8$ & $<---$ & $\mathrm{TD}$ & 1.279 & .202 & 6.339 & $* * *$ & par_22 \\
\hline $\mathrm{VR}_{27}$ & $<---$ & $\mathrm{TD}$ & 1.197 & .206 & 5.820 & $* * *$ & par_23 \\
\hline VR26 & $<---$ & TD & 1.522 & .276 & 5.504 & $* * *$ & par_24 \\
\hline $\mathrm{VR}_{35}$ & $<---$ & EFF & 1.000 & & & & \\
\hline$V_{34}$ & $<---$ & EFF & .662 & .187 & 3.536 & $* * *$ & par_25 \\
\hline$V_{3} 3$ & $<---$ & EFF & .869 & .175 & 4.975 & $* * *$ & par_26 \\
\hline$V_{12}$ & $<---$ & EFF & 1.200 & .193 & 6.209 & $* * *$ & par_27 \\
\hline $\mathrm{VR}_{31}$ & $<---$ & EFF & 1.154 & .179 & 6.459 & $* * *$ & par_28 \\
\hline $\mathrm{VR}_{40}$ & $<---$ & $\mathrm{EC}$ & 1.000 & & & & \\
\hline$V_{3} 9$ & $<---$ & EC & 1.356 & .194 & 6.990 & $* * *$ & par_29 \\
\hline $\mathrm{VR}_{3} 8$ & $<---$ & $\mathrm{EC}$ & .763 & .132 & 5.772 & $* * *$ & par_30 \\
\hline$V R_{37}$ & $<---$ & EC & 1.335 & 199 & 6.717 & $* * *$ & par_31 \\
\hline $\mathrm{VR}_{3} 6$ & $<---$ & $\mathrm{EC}$ & 1.106 & .160 & 6.914 & $* * *$ & par_32 \\
\hline
\end{tabular}


Table (3): Estimates of the Organizational Memory $n=158$

\begin{tabular}{|c|c|c|c|c|c|c|c|}
\hline & & & Estimate & S.E. & C.R. & $\mathrm{P}$ & Label \\
\hline VR45 & $<---$ & SK & 1.000 & & & & \\
\hline VR44 & $<---$ & SK & 1.054 & .115 & 9.195 & $* * *$ & par_1 \\
\hline VR43 & $<---$ & SK & 1.082 & .112 & 9.657 & $* * *$ & par_2 \\
\hline$V_{42}$ & $<---$ & SK & .916 & .099 & 9.211 & $* * *$ & par_3 \\
\hline $\mathrm{VR}_{41}$ & $<---$ & SK & 1.061 & .116 & 9.146 & $* * *$ & par_4 \\
\hline $\mathrm{VR}_{50}$ & $<---$ & JK & 1.000 & & & & \\
\hline VR49 & $<---$ & JK & .905 & .089 & 10.186 & $* * *$ & par_5 \\
\hline $\mathrm{VR}_{4} 8$ & $<---$ & JK & .964 & .100 & $9 \cdot 599$ & $* * *$ & par_6 \\
\hline$V_{4} 47$ & $<---$ & JK & .995 & .111 & 8.996 & $* * *$ & par_7 \\
\hline $\mathrm{VR}_{4} 6$ & $<---$ & JK & .794 & .106 & $7 \cdot 510$ & $* * *$ & par_8 \\
\hline VR55 & $<---$ & $\mathrm{COK}$ & 1.000 & & & & \\
\hline $\mathrm{VR}_{54}$ & $<--$ & $\mathrm{COK}$ & .812 & .093. & 8.729 & $* * *$ & par_9 \\
\hline VR53 & $<---$ & $\mathrm{COK}$ & .953 & .119 & 7.974 & $* * *$ & par_10 \\
\hline$V_{52}$ & $<---$ & $\mathrm{COK}$ & 1.021 & .124 & 8.226 & $* * *$ & par_11 \\
\hline $\mathrm{VR}_{51}$ & $<---$ & $\mathrm{COK}$ & .929 & .100 & 9.249 & $* * *$ & par_12 \\
\hline VR6o & $<---$ & IK & 1.000 & & & & \\
\hline VR59 & $<---$ & IK & 1.054 & .097 & 10.852 & $* * *$ & par_13 \\
\hline $\mathrm{VR}_{5} 8$ & $<---$ & IK & .477 & .067 & 7.132 & $* * *$ & par_14 \\
\hline $\mathrm{VR}_{57}$ & $<---$ & IK & .936 & .086 & 10.896 & $* * *$ & par_15 \\
\hline $\mathrm{VR}_{5} 6$ & $<---$ & IK & .715 & .080 & 8.932 & $* * *$ & par_16 \\
\hline VR65 & $<---$ & $\mathrm{H}$ & 1.000 & & & & \\
\hline VR64 & $<---$ & $\mathrm{H}$ & 1.232 & .159 & $7 \cdot 742$ & $* * *$ & par_17 \\
\hline VR63 & $<---$ & $\mathrm{H}$ & 1.461 & .164 & 8.887 & $* * *$ & par_18 \\
\hline VR62 & $<---$ & $\mathrm{H}$ & 1.016 & .129 & 7.860 & $* * *$ & par_19 \\
\hline VR61 & $<---$ & $\mathrm{H}$ & 1.358 & .153 & 8.898 & $* * *$ & par_2o \\
\hline VR7o & $<---$ & PK & 1.000 & & & & \\
\hline VR69 & $<---$ & PK & .954 & .087 & 10.949 & $* * *$ & par_21 \\
\hline VR68 & $<---$ & PK & .962 & .087 & 11.112 & $* * *$ & par_22 \\
\hline VR67 & $<---$ & PK & .635 & .082 & $7 \cdot 746$ & $* * *$ & par_23 \\
\hline VR66 & $<---$ & PK & .878 & .082 & 10.737 & $* * *$ & par_24 \\
\hline VR75 & $<---$ & CK & 1.000 & & & & \\
\hline VR74 & $<---$ & CK & 1.092 & .104 & 10.476 & $* * *$ & par_25 \\
\hline $\mathrm{VR}_{73}$ & $<---$ & CK & 1.087 & .098 & 11.041 & $* * *$ & par_26 \\
\hline$V_{72}$ & $<---$ & CK & 1.167 & .106 & 10.973 & $* * *$ & par_27 \\
\hline $\mathrm{VR}_{71}$ & $<---$ & CK & 1.166 & .130 & 8.940 & $* * *$ & par_28 \\
\hline
\end{tabular}

4.2 View and Analyze the Results of the Descriptive Analysis of Employees Retention Strategy

Table (4) shows means and standard deviations related to employee retention strategy, The responses reflected an overall mean reach (3.69), Indicates its high level, confirmed by the high harmony in the responses of the sample, which was reversed by the overall standard deviation reach (0.57), A low value, The level of the mean falls within the third category of the distribution of the scale categories according to the mean represented by the higher agreement, At the sub-dimension level, the results were as shown in Table (4), the Positive work environment, Employee involvement, Compensation \& benefits, Management support, Team working, Training \& Development, Employee freedom \& flexibility, Employee communication Showed total means reach (3.74) (3.55) (3.45) (3.63) (3.63) (3.88) (3.86) (3.79) Respectively, Which are high values Confirmed by the high harmony in the answers reflected by the 
standard deviation that reached (o.79) (o.81) (o.85) (o.81) (o.73) (o.55) (o.54) (o.6o) Respectively. The correlation coefficients between the sub-dimensions of the retention strategy are shown in Table (4) supporting the validity of scale construction since all sub-dimensions of the retention strategy are correlated significantly.

\subsection{View and Analyze the Results of the Descriptive Analysis of Organizational Memory}

Table (5) shows means and standard deviations related to organizational memory, The responses reflected an overall mean reach (3.90), Indicates its high level, confirmed by the high harmony in the responses of the sample, which was reversed by the overall standard deviation reach (0.55), A low value, The level of the mean falls within the third category of the distribution of the scale categories according to the mean represented by the higher agreement, At the sub-dimension level, the results were as shown in Table (5), the Social knowledge, Job knowledge, Corporate knowledge, Industry knowledge, History, Political knowledge, Cultural knowledge Showed total means reach (4.10) (4.02) (4.01) (4.00) (3.88) (3.59) (3.68) Respectively, Which are high values Confirmed by the high harmony in the answers reflected by the standard deviation that reached (o.59) (o.62) (o.61) (o.64) (o.69) (o.81) (o.77) Respectively. The correlation coefficients between the sub-dimensions of the retention strategy are shown in Table (5) supporting the validity of scale construction since all sub-dimensions of the retention strategy are correlated significantly.

Table (4): Means, Standard Deviations and Correlation Coefficients for Employees Retention Strategy $\mathrm{n}=158$

\begin{tabular}{|l|c|c|c|c|c|c|c|c|c|c|c|}
\hline Dimensions & $\mathrm{M}$ & $\mathrm{SD}$ & 1 & 2 & 3 & 4 & 5 & 6 & 7 & 8 & 9 \\
\hline Positive work environment & 3.74 & .79 & 1. & & & & & & & & \\
\hline Employee involvement & 3.55 & .81 & $.70^{* *}$ & 1. & & & & & & & \\
\hline Compensation \& benefits & 3.45 & .85 & $.71^{* *}$ & $.79^{* *}$ & 1. & & & & & & \\
\hline Management support & 3.63 & .81 & $.63^{* *}$ & $.69^{* *}$ & $.77^{* *}$ & 1. & & & & & \\
\hline Team working & 3.63 & .73 & $.53^{* *}$ & $.49^{* *}$ & $.60^{* *}$ & $.58^{* *}$ & 1. & & & & \\
\hline Training \& development & 3.88 & .55 & $.32^{* *}$ & $.44^{* *}$ & $.43^{* *}$ & $.46^{* *}$ & $.56^{* *}$ & 1. & & & \\
\hline Employee freedom \& flexibility & 3.86 & .54 & $.40^{* *}$ & $.53^{* *}$ & $.54^{* *}$ & $.52^{* *}$ & $.46^{*}$ & $.53^{* *}$ & 1. & & \\
\hline Employee communication & 3.79 & .60 & $.51^{* *}$ & $.56^{* * *}$ & $.61^{* *}$ & $.64^{* *}$ & $.61^{* *}$ & $.53^{* *}$ & $.64^{* *}$ & 1. & \\
\hline Total employee retention strategy & 3.69 & .57 & $.78^{* *}$ & $.84^{* *}$ & $.88^{* *}$ & $.85^{* *}$ & $.76^{* *}$ & $.64^{* *}$ & $.70^{* *}$ & $.79^{* *}$ & 1. \\
\hline
\end{tabular}

Table (5): Means, Standard Deviations and Correlation Coefficients for Organizational Memory n=158

\begin{tabular}{|c|c|c|c|c|c|c|c|c|c|c|}
\hline Dimensions & $\mathrm{M}$ & $\mathrm{SD}$ & 1 & 2 & 3 & 4 & 5 & 6 & 7 & 8 \\
\hline Social knowledge & 4.10 & .59 & 1. & & & & & & & \\
\hline Job knowledge & 4.02 & .62 & $.69^{* *}$ & 1. & & & & & & \\
\hline Corporate knowledge & 4.01 & .61 & $.65^{* *}$ & $.64^{* *}$ & 1. & & & & & \\
\hline Industry knowledge & 4.00 & .64 & $.65^{* *}$ & $.71^{* *}$ & $.72^{* *}$ & 1. & & & & \\
\hline History & 3.88 & .69 & $.56^{* *}$ & $.58^{* *}$ & $.66^{* *}$ & $.65^{* *}$ & 1. & & & \\
\hline Political knowledge & 3.59 & .81 & $.49^{* *}$ & $.51^{* *}$ & $.53^{* *}$ & $.56^{* *}$ & $.70^{* *}$ & 1. & & \\
\hline Cultural knowledge & 3.68 & .77 & $.47^{* *}$ & $.53^{* *}$ & $.51^{* *}$ & $.59^{* *}$ & $.57^{* *}$ & $.72^{* *}$ & 1. & \\
\hline Total organizational memory & 3.90 & .55 & $.77^{* *}$ & $.80^{* *}$ & $.81^{* *}$ & $.85^{* *}$ & $.83^{* *}$ & $.82^{* *}$ & $.79^{* *}$ & 1. \\
\hline
\end{tabular}

\subsection{Test the Impact of Employees Retention Strategy on Organizational Memory}

Table (6) shows the results of the impact models test, which indicate the significance of the impact of employees retention strategy on organizational memory, The value of $F$ (139.67), which is a high significance value at a level (o.o1), The explanatory power of this model was high according to the value of $\left(\mathrm{R}^{2}\right)$ of (o.47) This indicates that the retention strategy explains what $(47 \%)$ of the dependent variable 
of organizational memory, the simple regression equation of the influence model between the two variables was as follows:

Organizational memory $=\alpha+\beta$ employee retention strategy

Organizational memory $=(0.66)+(0.68)$

Table (6): Analytical Indicators of the Impact of Employees Retention Strategy on Organizational Memory

\begin{tabular}{|l|c|c|c|c|c|c|}
\hline Dimension & $\beta$ & $\alpha$ & $\mathrm{R}^{2}$ & $\mathrm{P}$ & $\mathrm{df}$ & $\mathrm{f}$ \\
\hline Employees retention strategy & 0.68 & 0.66 & 0.47 & 0.000 & 157 & 139.67 \\
\hline
\end{tabular}

The above results confirm the acceptance of the hypothesis that there is a significant effect of the employee retention strategy in the organizational memory at the macro level, at the sub-dimension level, table (7) summarizes the indicators of the analysis at the sub-dimension level as follows:

1. Positive work environment dimension achieved a significant effect in organizational memory, the value of $\mathrm{F}(37.85)$ calculated was greater than the tabular value at (0.05), Note that the value of the interpretation factor $\left(\mathrm{R}^{2}\right)$ reached (o.19), This means that Positive work environment explains (o.19) of the total changes in organizational memory, The value of $\beta$ (o.44) indicates that the change in Positive work environment in one unit will lead to a change of (o.44) in the organizational memory, These results allow acceptance of the first sub-hypothesis (there is a significant effect of Positive work environment in organizational memory).

2. Employee involvement dimension showed a significant effect in organizational memory, the value of $\mathrm{F}(75.60)$ calculated was greater than the tabular value at (0.05), Note that the value of the interpretation factor $\left(\mathrm{R}^{2}\right)$ reached (o.32), This means that Employee involvement explains (0.32) of the total changes in organizational memory, The value of $\beta$ (o.57) indicates that the change in Employee involvement in one unit will lead to a change of (o.44) in the organizational memory, These results allow acceptance of the second sub-hypothesis (there is a significant effect of Employee involvement in organizational memory).

3. Compensation \& benefits dimension achieved a significant effect in organizational memory, the value of $\mathrm{F}$ (37.59) calculated was greater than the tabular value at (0.05), Note that the value of the interpretation factor $\left(\mathrm{R}^{2}\right)$ reached (0.32), This means that Compensation \& benefits explain (0.32) of the total changes in organizational memory, The value of $\beta$ (0.56) indicates that the change in Compensation \& benefits in one unit will lead to a change of (o.56) in the organizational memory, These results allow acceptance of the third subhypothesis (there is a significant effect of Compensation \& benefits in organizational memory).

4. Management support dimension showed a significant effect in organizational memory, the value of $F(61.76)$ calculated was greater than the tabular value at (0.05), Note that the value of the interpretation factor $\left(\mathrm{R}^{2}\right)$ reached (0.28), This means that Management support explains (0.28) of the total changes in organizational memory, The value of $\beta$ (o.53) indicates that the change in Management support in one unit will lead to a change of (0.53) in the organizational memory, These results allow acceptance of the fourth sub-hypothesis (there is a significant effect of Management support in organizational memory).

5. Team working dimension achieved a significant effect in organizational memory, the value of F (67.65) calculated was greater than the tabular value at (0.05), Note that the value of the interpretation factor $\left(\mathrm{R}^{2}\right)$ reached (0.30), This means that Team working explain (0.30) of the total changes in organizational memory, The value of $\beta$ (o.55) indicates that the change in team working in one unit will lead to a change of (o.55) in the organizational memory, These results allow acceptance of the fifth sub-hypothesis (there is a significant effect of Team working in organizational memory). 
6. Training \& development dimension achieved a significant effect in organizational memory, the value of $\mathrm{F}$ (37.91) calculated was greater than the tabular value at (0.05), Note that the value of the interpretation factor $\left(\mathrm{R}^{2}\right)$ reached (o.19), This means that Training \& development explains (o.19) of the total changes in organizational memory, The value of $\beta$ (o.44) indicates that the change in Training \& development in one unit will lead to a change of (o.44) in the organizational memory, These results allow acceptance of the sixth sub-hypothesis (there is a significant effect of Training \& development in organizational memory).

7. Employee freedom \& flexibility dimension achieved a significant effect in organizational memory, the value of $F(88.83)$ calculated was greater than the tabular value at (0.05), Note that the value of the interpretation factor $\left(\mathrm{R}^{2}\right)$ reached (o.63), This means that Employee freedom \& flexibility explains (o.63) of the total changes in organizational memory, The value of $\beta$ (o.6o) indicates that the change in Employee freedom \& flexibility in one unit will lead to a change of (o.6o) in the organizational memory, These results allow acceptance of the seventh sub-hypothesis (there is a significant effect of Employee freedom \& flexibility in organizational memory).

8. Employee communication dimension achieved a significant effect in organizational memory, the value of $\mathrm{F}$ (150.15) calculated was greater than the tabular value at (0.05), Note that the value of the interpretation factor $\left(\mathrm{R}^{2}\right)$ reached (0.49), This means that Employee communication explains (o.49) of the total changes in organizational memory, The value of $\beta$ (o.70) indicates that the change in Employee communication in one unit will lead to a change of (0.70) in the organizational memory, These results allow acceptance of the eighth sub-hypothesis (there is a significant effect of Employee communication in organizational memory).

Table (7): Analytical Indicators of the Impact of Sub-dimensions of Employees Retention Strategy on Organizational Memory

\begin{tabular}{|l|c|c|c|c|c|c|}
\hline Dimensions & $\beta$ & $\alpha$ & $\mathrm{R}^{2}$ & $\mathrm{P}$ & $\mathrm{df}$ & $\mathrm{f}$ \\
\hline Positive work environment & 0.44 & 0.30 & 0.19 & 0.000 & 157 & 37.85 \\
\hline Employee involvement & 0.57 & 0.38 & 0.32 & 0.000 & 157 & 75.60 \\
\hline Compensation \& benefits & 0.56 & 0.36 & 0.32 & 0.000 & 157 & 73.59 \\
\hline Management support & 0.53 & 0.36 & 0.28 & 0.000 & 157 & 61.76 \\
\hline Team working & 0.55 & 0.41 & 0.30 & 0.000 & 157 & 67.65 \\
\hline Training \& development & 0.44 & 0.44 & 0.19 & 0.000 & 157 & 37.91 \\
\hline Employee freedom \& flexibility & 0.60 & 0.61 & 0.63 & 0.000 & 157 & 88.83 \\
\hline Employee communication & 0.70 & 0.64 & 0.49 & 0.000 & 157 & 150.15 \\
\hline
\end{tabular}

\section{Conclusions}

1. The results showed the existence of clear interest by the management of colleges surveyed on employees, in terms of giving them independence and improve the relationship between them and between senior management, reflecting its belief that it will give employees a sense of security and stability within the college, as well as increase retention as long as possible, and accordingly, its organizational memory will not be negatively affected.

2. The results proved that healthy working conditions within the colleges surveyed are acceptable, especially in terms of respect for employees and taking the proposals they make, but that there should be moral and material incentives gives to employees who submit proposals, and therefore, these practices will help colleges surveyed on receiving many proposals that may be good and solved many problems on the one hand, and increase retention for as long as possible, and not affected the organizational memory negatively.

3. The researchers noted a good interest from the colleges surveyed on the process of training 
and employee development, as there are training programs prepared in advance, and for each level of the college, which will help the feeling of employees that the colleges surveyed represent a working place gives them good care in terms of providing them with the necessary skills, and seek to develop it, thus, these practices will be a catalyst for the employees to stay in the colleges surveyed, and not affect organizational memory adversely.

4. The researchers found a good compensation system in the colleges surveyed, but at the same time, the researchers found that these compensations are often given on a general basis and not based on competence and excellence, this procedure may pay employees to look for another job, And if an employee gets best one, they will move to it, which will affect the organizational memory negatively.

5. The results showed that most employees in the colleges surveyed have a good knowledge of behaviors accepted within the workplace, which is proportionate with the work environment and, at the same time they have well-informed behaviors of the function, and how to perform the tasks required of them, and so the organization must seek to maintain these employees because of their loss It will mean damage to its organizational memory.

6. The results showed that most employees in the colleges surveyed have knowledge in the college history and the major turning points in colleges' past, and responsibility for its successes and failures, so the loss of these employees would negatively affect organizational memory in particular.

7. The researcher concluded that organizational memory levels in the colleges surveyed were good, and senior management at the college seeks to activate the organizational memory levels, but most attention found in the middle and senior management, while in the lower departments, the levels of interest low, Therefore, such a political in the future will decline organizational memory, Because of that most of these employees will be one-day promotions to middle and upper departments, So the colleges surveyed must activating the organizational memory at all levels.

8. The results showed that there is a significant effect of the employee retention strategy in the organizational memory, which mean that the activation procedures of, and increased attention to maintain employees and prevent them from moving to other organizations will help and affect the development and organizational memory, which will increase when employee stay on the organization for a longer duration, therefore, the experience, knowledge, and know-how about the procedures and rules of the organization will rise.

\section{Reference}

Ackerman, M and Halverson, C (1999) organizational memory: processes, boundary objects and trajectories, proceeding of the 32 Hawaii international conferences on system sciences.

Ahmad, S. (2013) Paradigms of Quality of Work Life, Journal of Human Values, Vol.19, No.1, pp.73-82.

AL-Ali, N (2003) comprehensive intellectual capital management step by step, john Wiley and Sons.

Al-Damoe, F.M., Yazam, M., and Bin Ahmidm K. (2012) The mediating effect of HRM outcomes (employee retention) on the relationship between HRM practice and organizational performance, international journal of human resource studies, vol.2, No.1, PP.75-88.

Anand, V., Manz, C., and Glick, W. (1998) an organizational memory approaches to information management, academy of management, Vol.23, No.4 pp. 796-809.

Apostolou, T., Hutchison, A.J., Boulton, A.J.M., Chak, W., Vileikyte, L., Uttley, L., \& Gokal, R. (200o) Quality of Life in CAPD, Transplant, and Chronic Renal Failure Patients with Diabetes, Renal Failure, Vol.29, No.2, pp.189197.

Armstrong, M. (2006) strategic Human Resource Management, a guide to action, 3 ed, kogan page, London

Atwood, M. (2002) organizational memory systems: challenges for information technology, proceeding of the $35^{\text {th }}$ Hawaii international conference on system science.

Barney, J. (1991) Firm resources and sustained competitive advantage, journal of management , Vol.17, No.1, pp.99120

Baron, A., \& Armstrong, M. (2007) Human capital management achieving, Kogan page 
Boeker, W. (1989) Strategic Change: The Effects Of Founding And History, Academy of Management Journal, Vol.32, N.3, pp.489-515.

Cam, D., Lefranc, H., Grados, M., \& Weston, J. (2018) Unequal growth and social capital in clothes-making enterprises in Peru: 1980-2015, journal of evolutionary studies in Business Vol.3, Iss.1, pp.198-225.

Chang, W., Wang, Y., and Huang, T. (2013) work design- related antecedents of turnover intention: A multilevel approach, human resource management, Vol.52. No.1, pp.1-28.

Conklin, J. (1997) designing organizational memory: preserving intellectual assets in knowledge Economy, Group Decision Support Systems, pp.1-35

Conner, K., and prahalad , C.K. (1996) A resource based Theory of the firm , Knowledge versus opportunism , organization science, Vol.7, pp.477-501.

Costello, A.B., \& Osborne, J.W. (2005) Best Practices in Exploratory Factor Analysis: Four Recommendations for Getting the Most from Your Analysis. Practical Assessment, Research and Evaluation, Vol.10, No.7 pp.1-9.

Cross, R., Davenport, T.H., and Cantrell, S. (2003), The social side of performance, MIT Sloan Management Review, Vol.45 No.1, pp.20-24.

Das, B.L., and Baruah, M. (2013) employee retention: a review of literature, journal of Business and management, vol.14, Iss,2, pp8-16.

Day, G.S. (1994) The capabilities of market-driven organizations, Journal of Marketing, Vol.58 No.4, pp. 37-52.

DeLong, D.W. (2004) Lost Knowledge: Confronting the Threat of an Aging Workforce, Oxford University Press, New York, NY.

Dessler, G. (2013) Human resource management, $13^{\text {th }}$ ed, pearson.

Dibble, S. (1999) Keeping Your Valuable Employees: Retention Strategies for Your Organization's Most Important Resource, John Wiley and Sons.

Disch, J. (2002) Creating healthy work environments. Creat Nurs. Vol.8, No.2, pp.3-4.

Drury, C.G. (2006) ergonomics human factor audits: in Karawowski, Waldemar (ed) international encyclopedia of ergonomics and human factor, vol.1, Taylor and Franceis.

Dunham, A., and Burt, C. (2011) Organizational memory and empowerment, journal of knowledge management, vol.15. Iss.5, pp.851-868.

Dunham, A., and Burt, C. (2014) Understanding employee knowledge: the development of an organizational memory scale, The Learning Organization, Vol. 21 No.2, pp.851-868.

Dysvik, A., \& Kuvaas, B. (2011) Intrinsic motivation as a moderator on the relationship between perceived job autonomy and work performance, European Journal of Work and Organizational, Vol.20, Iss.3, pp.367-387.

Eisenberger, R., Armeli, S., Rexwinkel, B., Lynch, P.D. and Rhoades, L. (2001) Reciprocation of perceived support, Journal of Applied Psychology, Vol.86 No.1, pp.42-51.

Fapohunda, T.M. (2011) Mentorship as Catalyst for Improving Human Capital Formation Of Women in Nigeria, British Journal of Arts and Social Sciences, Vol.3, No.2, pp.310-321.

Farooq, R. (2018) Developing a conceptual framework of knowledge management, International Journal of Innovation Science, Vol.11, Iss.1, pp-1757-2223.

Frank, F.D., Finnegan, R.P., and Taylor, C. R. (2004). The Race for Talent: Retaining and Engaging Workers in the 21st Century. Human Resource Planning, Vol.27, No.3, pp.12-25.

Gagne, M. (2014) the oxford Handbook; of work engagement, motivation and self-determination theory, oxford university press.

Gerogiannakis, S., Sintichakis, M., and Achilleopouluos, N. (2003) Collaborative knowledge management and Ontologies: the ONTO-LOGGING platform. Pp.127-138.

Girard, J. (2009) Building organizational memories: will you know what you know? Information. Information science reference, Hershey, New York.

Gittell, J.H., Godfrey, M., and Thistlethwaite, J. (2011) Interprofessional collaborative practice and relational coordination: Improving healthcare through relationships, Journal of Interprofessional Care, Vol.27, pp.210213.

Godwyn, M., and Gittel, J. (2012) sociology of organization, structures and relationships, SAGE.

Grant, R. M. (1996) Prospering in dynamically-competitive environments: organizational capability as knowledge integration, Organization Science, Vol.7, No.4, pp.375-87.

Green, S.B. (1991) How Many Subjects Does It Take to do a Regression Analysis, Multivariate Behavioral Research, Vol.26, No.3, pp.499-510.

Hatami, A., Galliers, R., and Huang, J. (2003) exploring the impacts of knowledge (Re) use and organizational memory on the effectiveness of strategic decision: A longitudinal case study, proceeding of the $36^{\text {th }}$ Hawaii international conference on system science. 
Hill, B., and Tande, C. (2006). Total Rewards: the employment Value Proposition. Workspan, Vol.10, No.6, pp. 1922.

Huang, C., Lin, H. C., and Chuang, C. H. (2006) Constructing factors related to worker retention. International Journal of Manpower, VOL.27, No.5, pp.491-508.

Idris, A. (2014) flexible working as an employee retention strategy in developing countries, journal of management research, Vol.14, No.2, pp.71-86.

Kiernan, W. E., and Knutson, K. (1990) Quality of Work Life, in Schalock R.L. (ed) Quality of Work Life Perspectives and Issues, American Association on mental retardation, pp.101-114.

Kiruthiga, V., and Magesh, R. (2014) Brunt of Employee Retention Strategies on Job Satisfaction, International Journal of Management and Commerce Innovations, Vol. 2, Iss.2.

Kling, J. (1995) High performance work system and firm performance, monthly labor review, pp.29-36.

Koenig, H., and Membrillo, A. (200o) Impact of individual knowledge on the increase of sustainable intellectual capital of organization - a systemic approach, available from http://www.bwi.uni-mannheiem.com.

Kotler, P. (200o) Marketing Management, prentice - Hall, Inc.

Kransdorff, A., and Williams, R. (2000) Managing organizational memory: The new competitive imperative, Organization Development Journal, Vol.18 No.1, pp.107-117.

Latha, K. L. (2013). A study on employee attrition and retention in manufacturing industries. Journal of Management Research, Vol.5, No.1, pp.1-23.

Li, Y.T., and Zhong y.Q. (2004) An Empirical Study on the Impact of Organizational memory on Organizational Performance in Manufacturing companies, Proceeding of the 37th Hawaii International Conference on System Science.

Mahal, P.K. (2012) HR practices as determinants of organizational commitment and employee retention, the IUP journal of management research, vol.11. no.4, pp.37-53.

Maier, R., Hadrich, T., \& Peinl, R. (2009) enterprise knowledge infrastructures, 2th ed, Springer.

Maslach, C., \& Jackson, S. E. (1986) Maslach Burnout Inventory: Manual. 2nd edition, Palo Alto, CA: Consulting Psychologists Press.

Mathimaran, B., and Kumar, A. (2017) employee retention strategies- an empirical research, global journal of management and business research, vol.17, Iss.1, pp.17-22.

Meifert, M. T. (2013) What is strategic about strategic HR development, in Meifert, M. T. (Ed) Strategic human resource development- a journey in eight stages, Heidelberg: Springer,3-23.

Mladkova, L. (2011) Knowledge management for knowledge worker, the electronic journal of knowledge management, Vol.9, Iss.3, pp.248-258.

Moncarz, E., Zhao, J., \& Kay, C. (2009) An Exploratory Study of U.S. Lodging Properties' Organizational Practices on Employee Turnover and Retention. International Journal of Contemporary Hospitality Management, Vol.21, No.4, pp. 437-458.

Moorman, C., and Miner, A. (1998) organizational improvisation and organizational memory, Academy of management review, vol,23. No.4, pp.698-723.

Morris, C. (2008) Healthy Work Environment Improves Care at Charles Morris, Pittsburgh regional health initiative. Pp.6-7.

Moutinho, L., and Hutcheson, G. D (2011) The SAGE Dictionary of Quantitative Management Research, SAGE.

Nadeem S., \& Aysha M., Tanveer, Y., and Tariq., H. (2011) Losing your best talent: Employee retention the dilemma of textile industry a case of textile sector. Interdisciplinary Journal of Contemporary Research in Business, Vol.3, No,8. Pp.896-9o6.

Niessen, C., and Volmer, J. (2010) Adaptation to increased work autonomy: The role of task reflection, European journal of work and organizational psychology, Vol.19, No.4, pp.442-46o.

No.3, pp.587-597.

Ones, D.S., 'Anderson, N., Sinangil, H.K., Viswesvaran, C. (2017) The Handbook of Industrial, Work E Organizational Psychology, 2th ed, SAGE reference.

Ongori, H. (2007) A review of the literature on employee turnover, African Journal of Business Management, pp. 49-54.

Pai, P., Miller, L.L., Honavar, V., and Wong, J. (2000) "Supporting organizational knowledge management with agents", in Khosrowpour, M. (eds) challenges of information technology management in the 21 st century, Pp.325-330, IRMA international conference,

Pennings, J. M., \& Harianto, F. (1992). Technological networking and innovation implementation. Organization science: A journal of the Institute of Management Sciences, Vol.3, No.3, pp.356-382.

Pfeffer, J. (1998) Seven practice of successful organization, California management review, Vol.4, No.2, PP.96-124. 
Phan, P.H., Venkataraman, S.S., Velamuri, R. (2008) Entrepreneurship in Emerging Regions Around the World: Theory, Evidence and implication, Edward Elgar.

Phillips, J., and Connell, A. (2003) Managing employee retention, a strategic accountability approach, Elsevier.

Price, A. (2004) Human Resource Management in a Business Context. 2nd edition. Thomson Learning.

Quinn, J.B. (1992) The intelligent enterprise: A New paradigm, Academy of management executive, Vol.6, No.4, pp.48-63.

Raghavan, Ram (2011) Human capital management challenges in india, chandos publishing.

Revlander, E., and Evans, M. (2007) strategies for improving employee retention, clinical leadership and management review, vol,21. Iss,2.

Schein, E. (2004), Organizational Culture and Leadership, 3rd ed, Jossey-Bass, San Francisco, CA.

Schermerhorn, J.R., Hunt, J.G., and Osborn, R.N. (2002) Organizational Behavior, $7^{\text {th }}$ ed, John Wiley \& Sons.

Schmitt, A., Borzillo, S., and Probst, G. (2012) Don't let knowledge walk away: Knowledge retention during employee downsizing, Management Learning, Vol.43, No.1, pp.53-74.

Seaman, J.T., and Smith, G.D. (2012) Your Company's History as a Leadership Tool, Harvard business review, December 2012 issue.

Sinha, C., and Sinha, R. (2012) factors effecting employee retention: a comparative analysis of two organizations from heavy engineering, European journal of Business and management, vol.4, No.3, pp145-162.

Spender, J.C., and Grant, R.M. (1997) Knowledge and the firm: overview, strategic management journal, Vol.17, Iss.s2, pp.5-9.

Stein, E., and Zwass, V. (1995) Actualizing organizational memory with information systems, information system research, Vol.6, No.2, pp.85-117.

Stewart, G., and Brown, K., (2011) Human resource management, linking strategy to practice, 2 th ed,Wiley.

Stijn, E., and Wensley, A. (2001) Organizational memory and the completeness of process modeling in ERP systems, come concerns methods and directions for future research, Business process management, vol.7, No.3, pp. 181194.

Stone D. N., Bryant, S. M., and Wier, B. (2010) Why are Financial Incentive Effects Unreliable? An Extension of SelfDetermination Theory. Behavioral Research in Accounting, Vol.22, No.2, pp.105-132.

Swamy, D.R. (2013) quality of work life of employee in private technical institutions, International Journal for Quality Research, Vol.7, No3, pp.3-14.

Sydler, R., Haefliger, S., Pruksa, R. (2013) Measuring intellectual capital with Financial Figures: can we predict profitability, European management journal, Vol.32, Iss.2, pp.244-259

Torrington, Derek. Hall, Laura and Taylor, Stephen (2008) Human Resource Management, $7^{\text {th }}$ ed, Prentice Hall Publisher.

Turniansky, B., and Hare, P. (1998) Individual in groups and organizations, 1 ed, sage publication.

Van Fleet, D., Fleet, E.V., and Seperich, G.J. (2014) Agribusiness: Principles of Management, Cengage learning

Varghese, S., \& Jayan, C. (2013) Quality of Work Life: A Dynamic Multidimensional Construct at Work Place - Part II, Guru Journal of Behavioral and Social Science, Vol.1, Iss.2, pp.91-104.

Vasantham, S., and Tephillah, S.C. (2016) Need and importance of employee retention to human resource management, Laxmi book publication.

Vispute, S. (2013) Recruitment strategy and employee retention in Indian Banking and insurance sector, International Journal of Arts \& Sciences, Vol.6, No.2, pp.743-756.

Walsh, J., and Ungson, G.R. (1991) Organizational memory, Academy of management, Vol.16. No.1, PP. 57-91.

Wang, M., Olson, D., and Shultz, K., (2013) Mid and late career issues: an integrative perspective, 1ed, Rutledge.

Ware, L. (2001) Employee retention and performance improvement in high-tech companies, performance improvement, Vol.40, No.2, pp.22-25.

Wernerfeld, B. (1984) A resource based view of the firm, strategic management journal, Vol.5, No.2, pp.171-18o.

Whitman, M.E., and Woszczynski, A.B. (2004) The Handbook of Information Systems Research, Idea group publishing. 